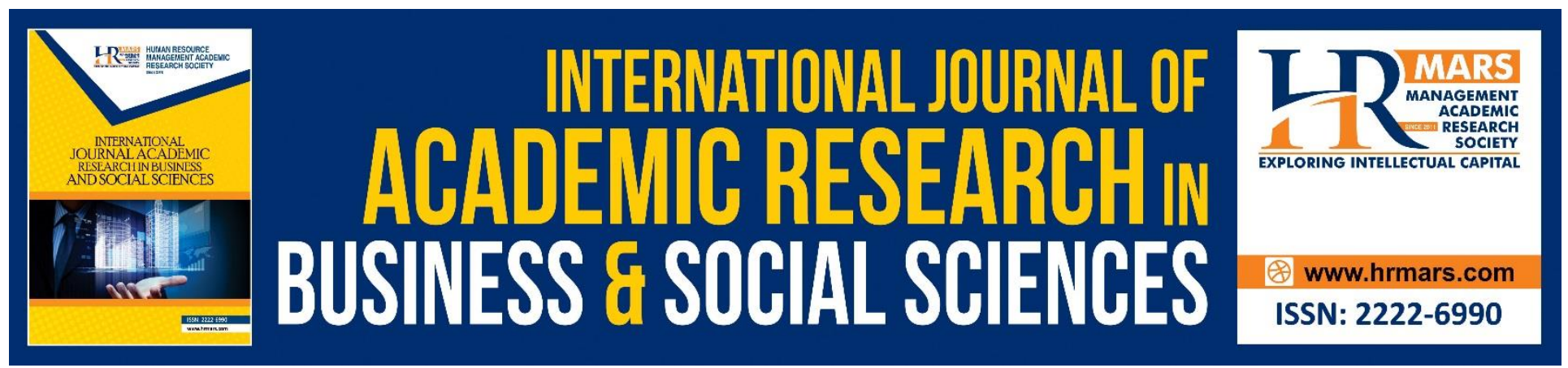

\title{
Improvement of Children's Imaginative Abilities by using Props through Creative Movement Activities
}

Muhammad Fazli Taib Saearani, Salman Alfarisi, Abdul Hamid Chan, Zolkipli Abdullah, Nurezlin Mohd Azib

To Link this Article: http://dx.doi.org/10.6007/IJARBSS/v9-i6/5927

DOI: $10.6007 /$ IJARBSS/v9-i6/5927

Received: 10 April 2019, Revised: 11 May 2019, Accepted: 01 June 2019

Published Online: 27 June 2019

In-Text Citation: (Saearani, Alfarisi, Chan, Abdullah, \& Azib, 2019)

To Cite this Article: Saearani, M. F. T., Alfarisi, S., Chan, A. H., Abdullah, Z., \& Azib, N. M. (2019). Improvement of Children's Imaginative Abilities by using Props through Creative Movement Activities. International Journal of Academic Research in Business and Social Sciences, 9(6), 118-124.

Copyright: (C) 2019 The Author(s)

Published by Human Resource Management Academic Research Society (www.hrmars.com)

This article is published under the Creative Commons Attribution (CC BY 4.0) license. Anyone may reproduce, distribute, translate and create derivative works of this article (for both commercial and non-commercial purposes), subject to full attribution to the original publication and authors. The full terms of this license may be seen at: http://creativecommons.org/licences/by/4.0/legalcode

Vol. 9, No. 6, 2019, Pg. 118 - 124

Full Terms \& Conditions of access and use can be found at http://hrmars.com/index.php/pages/detail/publication-ethics 


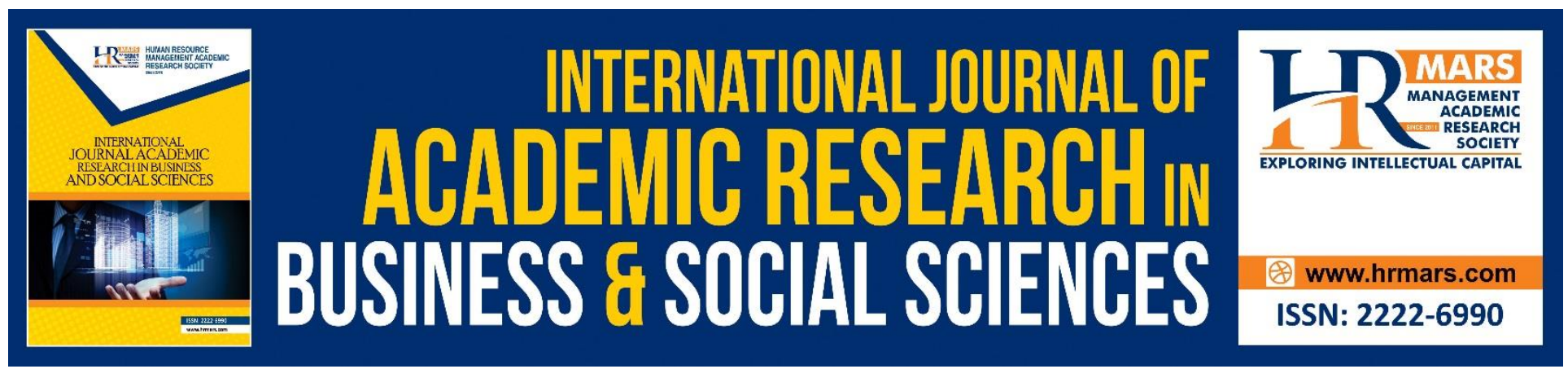

\title{
Improvement of Children's Imaginative Abilities by using Props through Creative Movement Activities
}

\author{
Muhammad Fazli Taib Saearani, Salman Alfarisi, \\ Abdul Hamid Chan, Zolkipli Abdullah \\ Department of Performing Arts, Faculty of Music and Performing Arts, Sultan Idris Education \\ University, Malaysia
}

Nurezlin Mohd Azib

Department of Music and Music Education, Faculty of Music and Performing Arts, Sultan Idris Education University, Malaysia

\begin{abstract}
Creative movement is one of the teaching and learning methods that helps to develop one's potential in communicating expressions creatively, applied through a series of movements. This type of learning relies on imaginations to explore movements, depending on the types of movements to be created. Exploration of creative movements by using variety of props lead to the freedom of ideas in creative imaginations. The ability to master the process of movements' creation by using props is essential in giving interpretations and forming the thoughts towards active and dynamic levels, to improve imaginative abilities. Therefore, this research was conducted to discover how the use of props helped in improving children's imaginative abilities through exploration of creative movements. Props were selected as tools and stimuli to enable the children to carry out imaginative explorations in movements, portraying their creative ideas. Important focus was given to kinesthetic stimulation in forming a series of movements to improve imaginative abilities, because children have their own ideas in creating desired movements. The important components such as usage of body, space, time, and energy were applied as the foundations in practicing creative movements. Qualitative method was used for this research, involving 16 subjects of 6-year-old children. Analyses by observations of participants and list of tasks to be accomplished were conducted to record the children's skills. Therefore, this research had given the chance for the children to develop their talents in imaginative abilities. Useful alternatives can also be gained, to give variety of teaching and learning methods based on children's exploration of imaginations, which can further lead to expressive communications through props and movements.
\end{abstract}

Keywords: Creative Movement, Props, Children, Imagination 


\section{Introduction}

According to Ramakrishnan (1998) and Ayob (1994), opening up opportunities in education towards creative directions, by implementing creative movements as extra module in teaching and learning, is a very useful alternative in implications of learning. Further, Leopold (1963) has stated that the use of props in creative movement activities will result in positive implications for teaching and learning activities. Therefore, if these are implemented in teaching, recreational and co-curricular activities in school, children will have good opportunities to explore and spread their inner talents in creative movements. This research aimed to give the opportunity for children in developing and improving their imaginative abilities through creative movement activities. The discussion includes the use of five types of props such as: (1) Hula hoop - a circular-shaped hoop made of plastic; (2) Pom-pom props made of plastic shredded into fine streamers; (3) Handkerchiefs - little square-shaped fabrics; (4) Ribbon - colored papers cut into long streamers; (5) Hand fan-folded semi-circular paper or fabric with holder made of plastic. This study also identified the implication of using props by the children after undergoing creative movement activities. These alternatives to conventional teaching methods were based on explorative abilities in order to project expressions by communicating through props and creative movements. According to Smith (2005), it has been stated that learning processes that incorporate the use of props in creative movements will provide the chance for the children to play around and explore their ideas to create interesting forms of movements. The ability to shape up the props in a variety of creative ways is also a good chance for children to develop their imaginations. Apart from that, interesting and unique creative space provided enables new knowledge to be absorbed and applied in the teaching and learning methods. This also relates to different experiences for different situations in teaching and learning as the medium of interaction for the children in order to achieve creative thinking skills (Mayer, 1989). Thus, in the research, the children were free to explore their imaginations and creative movements with their peers, as well as building up their own ideas and confidence. According to Wood (1990), there is generally a lack of freedom and opportunities given for children to express their ideas creatively and actively through movements. By taking this statement into consideration, this research also aimed to make the children realize on how to effectively use body movements by searching actively for creative ideas in forming these movements.

\section{Objective}

This research aims to examine the effects of using props through creative movement in improving students' imaginative abilities.

\section{Methodology}

Qualitative design was used for the research methodology. The researchers used the method of participant observation in collecting the data. Together with two instructors involved, the researchers conducted sessions of creative movement activities by using props with the subjects, who were 16 children aged 6 years old. There were 12 sessions conducted where the children were instructed to use the props provided, namely (1) Hula hoop, (2) Pom-pom, (3) Handkerchief, (4) Ribbon dan (5) Hand fan. These sessions were also recorded as data observation for the researchers 
INTERNATIONAL JOURNAL OF ACADEMIC RESEARCH IN BUSINESS AND SOCIAL SCIENCES

Vol. 9, No. 6, June, 2019, E-ISSN: 2222-6990 ㄷ 2019 HRMARS

to observe and analyze the children's levels of improvement in the creative movement activities.

\section{Research Findings}

These following explanations were the detailed analyses of observations carried out towards the children's use of props in the creative movement activities.

\section{Hula hoop}

Based on earlier observation on children's use of pom-pom hand props, the researchers found out that 8 children did not manage to complete the movement assignment by using hula hoop. From the observation, these children were just using the hula-hoop by just spinning them during activities with their teacher. Another 8 children managed to create several movements by using the hula hoop. In the earlier stage, it was observed that the children showed good response and enthusiasm by competing with each other to grab the hula-hoop props. On the second week, 5 out of 8 children observed, managed to successfully complete the movement assignment. However, 3 more children could not complete said assignment.

\section{Pom-pom}

In terms of the use of pom-pom, it was observed in the earlier stage that the children had never seen pom-pom props before, based on recognition questions asked by the researchers. Therefore, the children had never held and used pom-pom before. During the distribution of the props, it was observed that the children were just spinning the pom-pom around with their hands. Thus, lack of understanding and exploration on said props among the children, were observed at the beginning stage. Later, a total of 7 children managed to accomplish several movements in this activity, while 9 more children were still playing around and teasing their friends, and could not be controlled.

\section{Handkerchief}

The children managed to do several physical exercises such as jumping, running, and walking, while holding the handkerchief as props. They used the given space for movements, but it was also observed that several children did not follow the instructions given. The researchers had also instructed the children to form a circle by using the handkerchief props. Through this activity, 14 children managed to successfully follow the instructions and completed the activity. However, 2 children seemed quiet and non-cooperative. They just put the handkerchief props on their shoulders and could not complete the assignment.

\section{Ribbon}

The children showed extra interest and enjoyment during the distribution of the ribbon props, showing that they liked the items. They managed to explore several movements with the ribbon props based on their own creative ideas. Thus, it was observed by the researchers that the ribbon props were the easiest to be used by the children for creative movement activities. It was seen that only 3 out of 16 children who could not manage to carry out movement activities by using the ribbons. It was therefore derived that the 3 children were more interested to use other props.

\section{Hand fan}

The researchers distributed hand fan props to the children. It was observed that most of the children encountered difficulty to fold and unfold the hand fans. This was also because of their small hands. However, 6 children showed prior knowledge and recognition of the use of hand fans, thus they managed the props more easily. The researchers demonstrated easy steps of movements such 
as spinning around and turning to the left and right while holding and moving the hand fans. 6 children showed interest in the activity and they did the movements well. However, 10 children were still hesitating in doing the movements. They made mistakes in following the order of movements, and also did not focus well.

Based on the activities conducted by the researchers and instructors, it was observed that the children had improved in using props through creative movements. It was analyzed that there was a certain level of improvement in each session recorded. The improvement comprised of the ability to respond to the music that accompanied their movements, moving specifically following the tempo, and forming synchronized movements. Apart from that, the researchers could observe the children's imaginative abilities through their creative movements by making use of the body, space, tempo, energy, and time factors. The successful development of imaginations here refer to how the children responded well from the instructions given, forming various creative movements from session to session. The development of children's imaginative abilities was also observed when they no longer merely copied their instructors' movements, but came up with their own ideas to portray their desired movements instead. However, there were a few children who could not successfully develop their imaginative abilities.

Based on the interview with their teachers, it was discovered that this group of children were naturally quiet, introvert and inactive in class, resulting in them encountering difficulty to improve in the activities. Besides that, it was also reported by the teacher that there was a lack of creative activities done in the kindergarten, therefore some children might not easily get used to such activities in the research. From several activities carried out throughout the 12 sessions, the researchers had also observed that there was a significant improvement in the children's ability to understand and respond to the instructions in creative movements. A good example was portrayed in the teamwork effort of the children, where successful communication and the spirit of working together, managed to be achieved by the children.

The good communication achieved lead to the successful variety of creative and unique movements created by using the props provided. The children were also observed to have better grasp and control in their movements' directions and formations. For example, in the earlier stages, the children were always confused whether to move to the left or right, or up and down in their movements and props, but they became more synchronized as the sessions went on. They had also improved in following the correct rhythm and tempo during the later sessions of creative movement activities. 


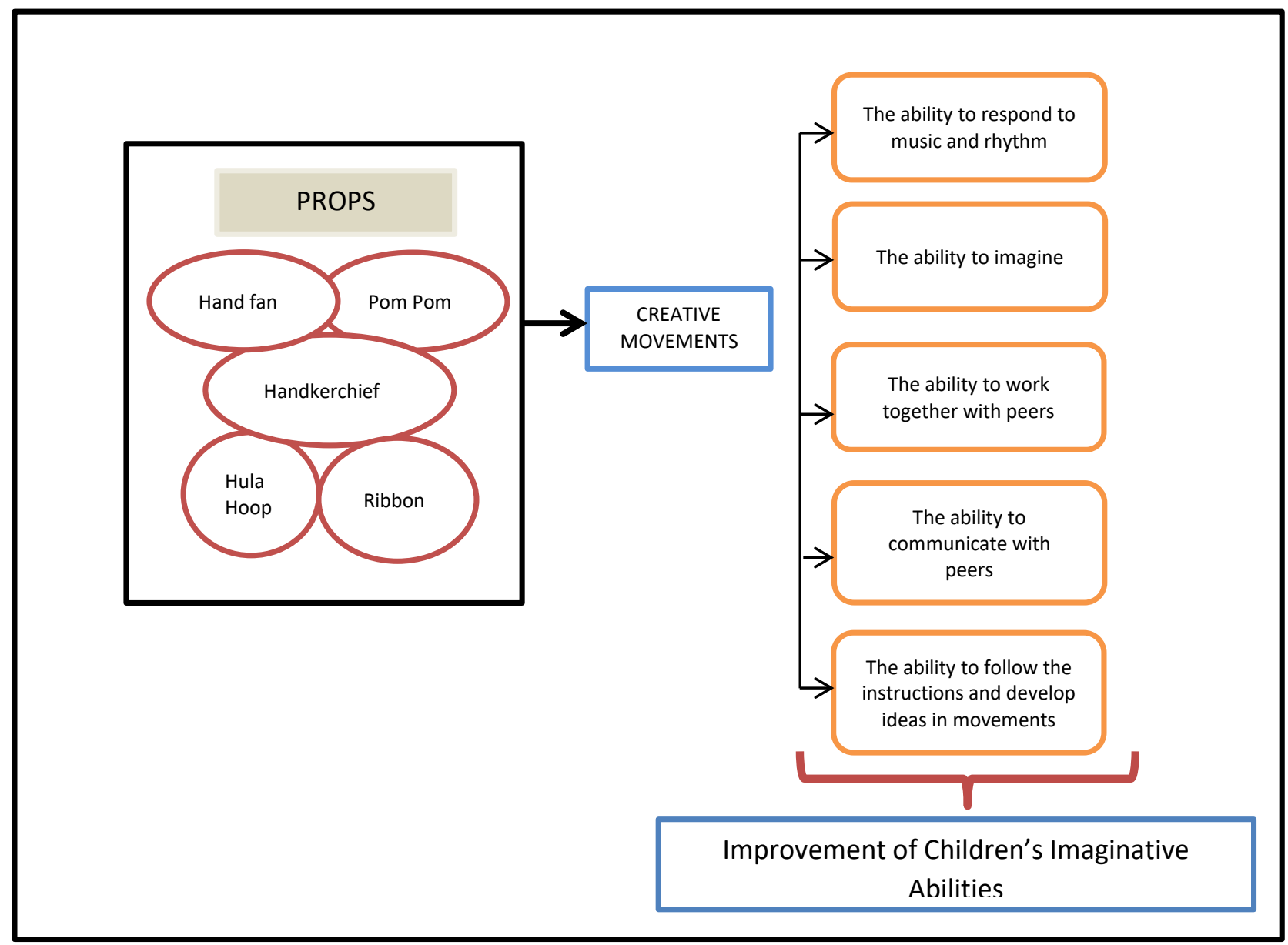

\section{Diagram: The effects of using of props through creative movement in improving students} imaginative abilities (Taib, 2019)

\section{Conclusion}

From this research, it is concluded that the experience in improving the performance of children through creative movement activities by using props relate to how the exploration activities can provide them with an active stimulus to think, find and display the skills available to be performed through the movements. More specifically in details, the research concludes that:

(1) Creative movements have helped to improve the children's potentials in imaginative abilities through exploration and creation of desired movements to portray.

(2) The props enabled the children to explore, build and create their forms of movements more creatively and imaginatively. Based on this research, the 16 respondents chosen from the children involved had undergone exploratory processes by using body, energy, and rhythm factors in the beginning stage.

(3) Most of the children showed good interest, but there were also several who could not improve more in imaginative abilities, as well as lacking focus during the movements' exploration processes. 
The researchers also observed and stated that the teacher who conducted the activities should attract the children's attention first to ensure eager participation from them. If the children were keenly interested, they would voluntarily participate in the activity from the beginning until the completion of the activity. It was also observed that the children were excited to participate more upon seeing colorful props, therefore colors played an important role for the props used. Hence, creative movements should be implemented on a continuous stage in the teaching and learning activities. This is because it helps the children to create imaginative and creative movements by using the props' aid too. Apart from that, the use of music is also important to children to help stimulate their minds creatively, in order to portray their desired movements clearly. The researchers felt that the time was spent meaningfully and productively in the creative movement processes with the children, due to the children's inquisitive in learning, as well as their understanding and openness to the experience. The children were also very honest and innocent in getting from one task to another in the creative movement processes. Therefore, this helps the researchers to shape up the activities well, and also to assign teachers that the children like and could cooperate with, for the creative movement activities.

\section{Acknowledgements}

This research is funded by University Research Grant (2017-0293-107-01) from Universiti Pendidikan Sultan Idris (UPSI). We would like to express our thanks and appreciation to the National Children Development Research Center, UPSI.

\section{Corresponding Author}

Muhammad Fazli Taib Saearani

Department of Performing Arts, Faculty of Music and Performing Arts, Sultan Idris Education University, 35900, Tanjung Malim, Perak, Malaysia.

Email: salman@fmsp.upsi.edu.my

\section{References}

Leopold, W. D. (1963). Creativity education: Some theories and procedures to enhance the development of creativity within the classroom seeting. Doctoral Thesis. Abstract International.

Mayer, R. E. (1989). Cognitive views of creativity: Creative teaching for creative learning. Contemporary Educational Psychology, 5, 145-149.

Saearani, M. F. T. \& Shafii, A. S. H. (2009). Pengaplikasian Pendidikan Tari berbentuk Pergerakan Kreatif di kalangan Pelajar Sekolah Menengah. Isu-Isu Sastera dan Budaya: Kertas Prosiding Persidangan Seni Kebangsaan, Sekolah Pengajian Seni, Universiti Malaysia Sabah.

Ramakrishnan, P. Y. (1998). Pendidikan Pergerakan Mudah. Shah Alam: Fajar Bakti Sdn.Bhd.

Smith-Autard, J. (1994). The Art of Dance in Education. London: A\&Black Publishers.

Ayob, S. (1996). Strategi, Teknik dan Perancangan Pendidikan Pergerakan. Kuala Lumpur: Flo Enterprise.

Wood, J. (1990). Implementing Developmentally Appropriate Classroom. Annual Conference of the Southern Association on Children. Under Si, Dallas: TX. 